\title{
Water adsorption and hygroscopic growth of six anemophilous pollen species: the effect of temperature
}

\author{
Mingjin Tang ${ }^{1,5,6}$, Wenjun Gu ${ }^{1,5}$, Qingxin $\mathrm{Ma}^{2,5,6}$, Yong $\mathrm{Jie} \mathrm{Li}^{3}$, Cheng Zhong ${ }^{2,5}$, Sheng $\mathbf{L i}^{1,5}$, Xin Yin ${ }^{1,5}$, \\ Ru-Jin Huang ${ }^{4,7}$, Hong $\mathrm{He}^{2,5,6}$, and Xinming Wang ${ }^{1,5,6}$ \\ ${ }^{1}$ State Key Laboratory of Organic Geochemistry and Guangdong Key Laboratory of Environmental Protection and Resources \\ Utilization, Guangzhou Institute of Geochemistry, Chinese Academy of Sciences, Guangzhou 510640, China \\ ${ }^{2}$ State Key Joint Laboratory of Environment Simulation and Pollution Control, Research Center for Eco-Environmental \\ Sciences, Chinese Academy of Sciences, Beijing 100085, China \\ ${ }^{3}$ Department of Civil and Environmental Engineering, Faculty of Science and Technology, University of Macau, \\ Avenida da Universidade, Taipa, Macau, China \\ ${ }^{4}$ Key Laboratory of Aerosol Chemistry and Physics, State Key Laboratory of Loess and Quaternary Geology, \\ Institute of Earth and Environment, Chinese Academy of Sciences, Xi'an 710061, China \\ ${ }^{5}$ University of Chinese Academy of Sciences, Beijing 100049, China \\ ${ }^{6}$ Center for Excellence in Regional Atmospheric Environment, Institute of Urban Environment, \\ Chinese Academy of Sciences, Xiamen 361021, China \\ ${ }^{7}$ Center for Excellence in Quaternary Science and Global Change, Xi' an 710061, China
}

Correspondence: Mingjin Tang (mingjintang@gig.ac.cn) and Qingxin Ma (qxma@rcees.ac.cn)

Received: 20 October 2018 - Discussion started: 19 November 2018

Revised: 13 February 2019 - Accepted: 15 February 2019 - Published: 21 February 2019

\begin{abstract}
Hygroscopicity largely affects environmental and climatic impacts of pollen grains, one important type of primary biological aerosol particles in the troposphere. However, our knowledge of pollen hygroscopicity is rather limited, and the effect of temperature in particular has rarely been explored before. In this work three different techniques, including a vapor sorption analyzer, diffusion reflectance infrared Fourier transform spectroscopy (DRIFTS) and transmission Fourier transform infrared spectroscopy (transmission FTIR) were employed to characterize six anemophilous pollen species and to investigate their hygroscopic properties as a function of relative humidity ( $\mathrm{RH}$, up to $95 \%$ ) and temperature $\left(5\right.$ or 15,25 and $\left.37^{\circ} \mathrm{C}\right)$. Substantial mass increase due to water uptake was observed for all the six pollen species, and at $25^{\circ} \mathrm{C}$ the relative mass increase at $90 \% \mathrm{RH}$, when compared to that at $<1 \% \mathrm{RH}$, ranged from $\sim 30 \%$ to $\sim 50 \%$, varying with pollen species. It was found that the modified $\kappa$-Köhler equation can well approximate mass hygroscopic growth of all the six pollen species, and the single hygroscopicity parameter $(\kappa)$ was determined to be in the range of $0.034 \pm 0.001$ to $0.061 \pm 0.007$ at $25^{\circ} \mathrm{C}$. In situ
\end{abstract}

DRIFTS measurements suggested that water adsorption by pollen species was mainly contributed to by $\mathrm{OH}$ groups of organic compounds they contained, and good correlations were indeed found between hygroscopicity of pollen species and the number of $\mathrm{OH}$ groups, as determined using transmission FTIR. An increase in temperature would in general lead to a decrease in hygroscopicity, except for pecan pollen. For example, $\kappa$ values decreased from $0.073 \pm 0.006$ at $5^{\circ} \mathrm{C}$ to $0.061 \pm 0.007$ at $25^{\circ} \mathrm{C}$ and to $0.057 \pm 0.004$ at $37^{\circ} \mathrm{C}$ for Populus tremuloides pollen, and decreased from $0.060 \pm 0.001$ at $15^{\circ} \mathrm{C}$ to $0.054 \pm 0.001$ at $25^{\circ} \mathrm{C}$ and $0.050 \pm 0.002$ at $37^{\circ} \mathrm{C}$ for paper mulberry pollen.

\section{Introduction}

Primary biological aerosol particles (PBAPs), an important type of aerosol particles in the troposphere, are directly emitted from the biosphere and include pollen, fungal spores, bacteria, viruses, algae and so on (Després et al., 2012; Fröhlich-Nowoisky et al., 2016). Emission and abundance of 
PBAPs are quite uncertain, and annual emission fluxes are estimated to be in the range of $<10$ to $\sim 1000 \mathrm{Tg}$ for total PBAPs and 47-84 Tg for pollen (Després et al., 2012). Pollen, and PBAPs in general, are of great concern due to their various impacts on the Earth's system (Sun and Ariya, 2006; Ariya et al., 2009; Georgakopoulos et al., 2009; Morris et al., 2011, 2014; Fröhlich-Nowoisky et al., 2016). For example, they can be allergenic, infectious or even toxic, affecting the health of humans and other species in the ecological systems over different scales (Douwes et al., 2003; Reinmuth-Selzle et al., 2017; Shiraiwa et al., 2017). The geographical dispersion of anemophilous plants largely relies on pollen dispersal, which in turn depends on the emission, transport and deposition of pollen grains; therefore, pollen plays a key role in the evolution of many ecosystems (Womack et al., 2010; Fröhlich-Nowoisky et al., 2016). In addition, PBAPs can serve as giant cloud condensation nuclei (CCN) and ice-nucleating particles (INPs), significantly impacting the formation and properties of clouds and thus radiative balance and precipitation (Möhler et al., 2007; Ariya et al., 2009; Pratt et al., 2009; Pope, 2010; Pummer et al., 2012; Gute and Abbatt, 2018). It has also been proposed that PBAPs may have significant impacts on chemical composition of aerosol particles via heterogeneous and multiphase chemistry (Deguillaume et al., 2008; Estillore et al., 2016; Reinmuth-Selzle et al., 2017; Shiraiwa et al., 2017).

Hygroscopicity is one of the most important physicochemical properties of pollen (as well as aerosol particles in general). Hygroscopicity largely impacts the transport and deposition of pollen grains (Sofiev et al., 2006), therefore affecting their lifetimes, abundance and spatiotemporal distribution. In addition, hygroscopicity is closely linked to the ability of aerosol particles to serve as CCN and INPs (Petters and Kreidenweis, 2007; Kreidenweis and Asa-Awuku, 2014; Laaksonen et al., 2016; Tang et al., 2016). Several previous studies have measured the hygroscopicity and CCN activities of pollen (Diehl et al., 2001; Pope, 2010; Griffiths et al., 2012; Lin et al., 2015; Steiner et al., 2015; Prisle et al., 2018) and other PBAPs such as bacteria (Pasanen et al., 1991; Reponen et al., 1996; Franc and DeMott, 1998; Ko et al., 2000; Lee et al., 2002; Bauer et al., 2003). For example, water uptake of 11 pollen species was studied using an analytical balance (Diehl et al., 2001), and the mass of pollen was found to be increased by $3 \%-16 \%$ at $73 \%$ RH and by $~ 100 \%-$ $300 \%$ at $95 \% \mathrm{RH}$, compared to that at $<1 \% \mathrm{RH}$. An electrodynamic balance was employed to investigate hygroscopic growth of eight types of pollen (Pope, 2010; Griffiths et al., 2012), and it was found that their hygroscopic growth can be approximated by the modified $\kappa$-Köhler equation, with single hygroscopicity parameters being around 0.1 (depending on the assumed pollen density, as discussed in Sect. 3.2).

Previous measurements were mostly carried out at or close to room temperature, and the effects of temperature on hygroscopic properties of pollen and other types of PBAPs are yet to be elucidated. To our knowledge, only one pre- vious study (Bunderson and Levetin, 2015) explored the effect of temperature $\left(4,15\right.$ and $\left.20^{\circ} \mathrm{C}\right)$ on water uptake by Juniperus ashei, Juniperus monosperma and Juniperus pinchotii pollen. It is important to account for the temperature effects, because ambient temperatures range from below -70 to $>30^{\circ} \mathrm{C}$ in the troposphere. In particular, the altitude of $0.5-2.0 \mathrm{~km}$ to which pollen can be easily transported (Noh et al., 2013) may have temperatures close to or lower than the chilling temperatures for vegetative species (up to $16.5^{\circ} \mathrm{C}$ ) (Melke, 2015). Moreover, the temperature in the respiratory tract can reach up to $37^{\circ} \mathrm{C}$ (the physiological temperature). In the work presented here, a vapor sorption analyzer (VSA) was employed to investigate hygroscopic growth of pollen grains at different temperature ( 5 or 15,25 and $37^{\circ} \mathrm{C}$ ), a range covering the chilling temperature to the physiological temperature. Water uptake by pollen was also examined using diffusion reflectance infrared Fourier transform spectroscopy at room temperature to complement the VSA results. Furthermore, transmission Fourier transformation infrared spectroscopy was used to characterize functional groups of dry pollen grains, in an attempt to seek potential links between chemical composition of pollen grains and their hygroscopic properties.

\section{Experimental sections}

Six pollen species, all from anemophilous plants, were investigated in this work, including Populus tremuloides and Populus deltoides (provided by Sigma Aldrich) as well as ragweed, corn, pecan and paper mulberry (provided by Polysciences, Inc.). The six pollen species were chosen in our work primarily because they were commercially available. Furthermore, these plants are also widely distributed in the globe. For example, corn is the most produced grain in the world (International Grains Council, 2019), and up to $50 \%$ of pollen-related allergic rhinitis cases in North America are caused by ragweed pollen (Taramarcaz et al., 2005).

\subsection{Fourier transformation infrared spectroscopy}

The adsorption of water by pollen species was studied using in situ diffusion reflectance infrared Fourier transform spectroscopy (DRIFTS) at room temperature $\left(\sim 25^{\circ} \mathrm{C}\right)$. This technique was described in detail in our previous work (Ma et al., 2010), and similar setups have also been used by other groups to investigate the adsorption of water by mineral dust (Joshi et al., 2017; Ibrahim et al., 2018). Infrared spectra were recorded using a Nicolet 6700 Fourier transformation infrared spectrometer (FTIR, Thermo Nicolet Instrument Corporation), equipped with an in situ diffuse reflection chamber and a high-sensitivity mercury cadmium telluride (MCT) detector cooled by liquid nitrogen. A pollen sample (about $10 \mathrm{mg}$ for each sample) under investigation was placed into a ceramic crucible, which was located in the in 
situ chamber. A dry airflow and a humidified airflow were first mixed and then delivered into the chamber, and the total flow rate was set to $200 \mathrm{~mL} \mathrm{~min}^{-1}$ (standard condition). Relative humidity (RH) in the chamber could be adjusted by varying the flow rate ratio of the dry flow to the humidified flow and was monitored online using a moisture meter (CENTER 314) with an absolute uncertainty of $\pm 2 \%$. Prior to each experiment, the sample was flushed with dry air for $3 \mathrm{~h}$ at $25^{\circ} \mathrm{C}$, and the reference spectrum was recorded after the pretreatment. Infrared spectra were collected and analyzed using OMNIC 6.0 software (Nicolet Corp.). All the spectra reported here were recorded with a wave number resolution of $4 \mathrm{~cm}^{-1}$, and 100 scans were averaged to produce a spectrum. Water adsorption was equilibrated for at least $30 \mathrm{~min}$ at each RH to ensure that the equilibrium between water vapor and adsorbed water was reached.

Pollen samples used in this work were also characterized using transmission FTIR equipped with a deuterated triglycine sulfate detector (DTGS) detector. Pollen grains and $\mathrm{KBr}$ were mixed with a mass ratio of approximately $1: 100$ and ground in an agate mortar, and the mixture was then pressed into a clear disc. Transmission FTIR was employed to examine these discs, and a pure $\mathrm{KBr}$ disc was used as the reference. All the spectra, each of which was the average of 100 scans, were also recorded with a wave number resolution of $4 \mathrm{~cm}^{-1}$.

\subsection{Vapor sorption analyzer}

Hygroscopic growth of pollen grains was further investigated using a vapor sorption analyzer (Q5000 SA, TA Instruments, New Castle, DE, USA) described in our previous work ( $\mathrm{Gu}$ et al., 2017; Guo et al., 2019; Jia et al., 2018). In brief, this instrument measured the sample mass as a function of $\mathrm{RH}$ under isothermal conditions. The instrument can be operated in the temperature range of $5-85^{\circ} \mathrm{C}$ with a temperature accuracy of $\pm 0.1{ }^{\circ} \mathrm{C}$ and in the RH range of $0 \%-98 \%$ with an absolute accuracy of $\pm 1 \%$. RH in the humidity chamber was regulated by using two mass flow controllers to control the dry and humidified nitrogen flows very precisely. The accuracy in RH control was routinely checked by measuring the DRH values for a series of standard compounds, e.g., $\mathrm{NaCl},\left(\mathrm{NH}_{4}\right)_{2} \mathrm{SO}_{4}$ and $\mathrm{KCl}$, and the difference between the measured and theoretical DRH was always $<1 \%$. The mass measurement had a range of $0-100 \mathrm{mg}$ and a sensitivity of $\pm 0.01 \mu \mathrm{g}$. The initial mass of each sample used in this work was in the range of $0.5-1 \mathrm{mg}$. For each of the first three types of pollen species (Populus tremuloides, Populus deltoides and ragweed pollen), three samples in total were investigated, and each sample was studied under isothermal conditions at 5,25 and $37^{\circ} \mathrm{C}$. For each of the other three types of pollen species (corn, pecan and paper mulberry pollen), experiments were carried out at $15^{\circ} \mathrm{C}$ instead of $5^{\circ} \mathrm{C}$, because the instrument could only be cooled down to $15^{\circ} \mathrm{C}$ due to a

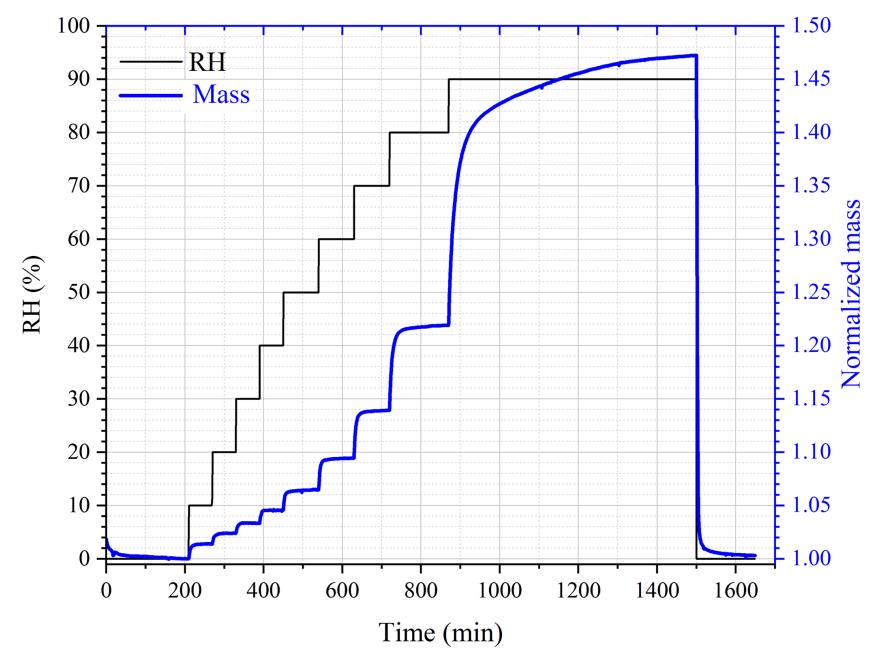

Figure 1. Change in RH (black curve, left $y$ axis) and normalized sample mass (blue curve, right $y$ axis) with time for a typical experiment in which hygroscopic growth of pollen grains was measured. In this figure a data set for paper mulberry pollen at $25^{\circ} \mathrm{C}$ is plotted as an example.

technical problem after we finished experiments for the first three pollen species.

For the first sample, at each temperature the sample was first dried at $0 \% \mathrm{RH}$ (the actual $\mathrm{RH}$ was measured to be $<1 \%$ ); after that, RH was increased stepwise to $95 \%$ with an increment of $5 \%$ per step and then switched back to $<1 \%$ to dry the sample again. At each RH, the sample was equilibrated with the environment (i.e., until the sample mass became stable) before RH was changed to the next value, and the sample mass was considered to be stabilized when the mass change was $<0.05 \%$ within $30 \mathrm{~min}$. Such a measurement at one temperature could take several days. In order to reduce experimental time, the second and third samples were investigated in a similar way to the first sample, except that RH was increased stepwise to $90 \%$ with an increment of $10 \%$ per step. A typical experimental data set is displayed in Fig. 1, as an example to illustrate the change in $\mathrm{RH}$ and normalized sample mass with experimental time.

\section{Results and discussion}

\subsection{FTIR characterization of pollen samples}

\subsubsection{Infrared spectra of dry pollen samples}

Figure 2 shows the transmission FTIR spectra of the six pollen species investigated in our work, and peak assignments can be found in Table 1. A broad band in the range of $3600-3000 \mathrm{~cm}^{-1}$, attributed to $\mathrm{O}-\mathrm{H}$ stretching vibration (Stuart, 2004; Pummer et al., 2013), and two sharp peaks at 2920 and $2850 \mathrm{~cm}^{-1}$, attributed to $\mathrm{C}-\mathrm{H}$ stretching (Eliason et al., 2003; Stuart, 2004; Pummer et al., 2013), were ob- 


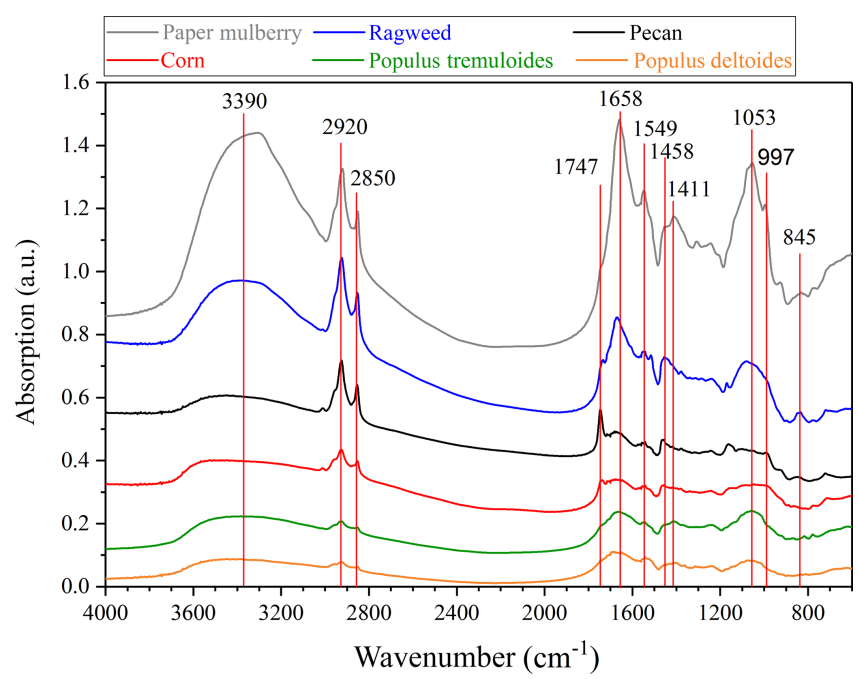

Figure 2. Transmission FTIR spectra of six pollen species investigated in this work.

served for all the pollen species. The two peaks at 1747 and $1658 \mathrm{~cm}^{-1}$ were assigned to alkyl ester carbonyls (Pappas et al., 2003; Najera et al., 2009; Pummer et al., 2013), and the two peaks at 1549 and $1458 \mathrm{~cm}^{-1}\left(1411 \mathrm{~cm}^{-1}\right.$ for paper mulberry pollen) were assigned to $\mathrm{C}=\mathrm{C}$ stretching and $\mathrm{H}-\mathrm{C}-\mathrm{H}$ deformation (Stuart, 2004; Pummer et al., 2013). In addition, the three peaks at 1053,997 and $845 \mathrm{~cm}^{-1}$ were assigned to $\mathrm{C}-\mathrm{O}$ stretching, $\mathrm{C}-\mathrm{C}$ stretching and $\mathrm{C}-\mathrm{H}$ out-of-plane bending, respectively (Stuart, 2004; Najera et al., 2009; Pummer et al., 2013).

$\mathrm{OH}$ groups and $\mathrm{C}-\mathrm{H}$ groups in organic compounds are generally considered to be hydrophilic and hydrophobic, and one may expect that the number of $\mathrm{OH}$ groups (relative to that of $\mathrm{C}-\mathrm{H}$ groups) that organic samples contain may affect their hygroscopicity. For example, it was found in many previous studies (Eliason et al., 2003; Asad et al., 2004; Hung et al., 2005; Najera et al., 2009) that heterogeneous reactions of organic materials with $\mathrm{O}_{3}$ and $\mathrm{OH}$ radicals would increase the IR absorption intensity for the $\mathrm{O}-\mathrm{H}$ stretching mode and decrease the IR absorption intensity for the $\mathrm{C}-\mathrm{H}$ stretching mode, meanwhile leading to the enhancement in their hygroscopicity. Therefore, in this work we use the intensity ratio of the $\mathrm{O}-\mathrm{H}$ stretching vibration band $\left(3000-3600 \mathrm{~cm}^{-1}\right)$ to the $\mathrm{C}-\mathrm{H}$ stretching mode $\left(2920 \mathrm{~cm}^{-1}\right)$ to qualitatively represent the number of $\mathrm{OH}$ groups pollen samples contain. As shown in Fig. 2, the six pollen species examined in our work can be roughly classified into two catalogues: (1) for Populus deltoides, Populus tremuloides and paper mulberry pollen, the $\mathrm{O}-\mathrm{H}$ stretching vibration band is more intensive than the $\mathrm{C}-\mathrm{H}$ stretching mode, indicating that they contain relatively high levels of OH groups; (2) for ragweed, pecan and corn pollen, the $\mathrm{O}-\mathrm{H}$ stretching vibration band is less intensive than the $\mathrm{C}-\mathrm{H}$ stretching mode, indicating that they contain relatively low levels of $\mathrm{OH}$ groups. The relation between the number of
Table 1. Vibrational mode assignment for six pollen species investigated in this work.

\begin{tabular}{ll}
\hline Wave number $\left(\mathrm{cm}^{-1}\right)$ & Vibrational mode \\
\hline $3600-3000$ & O-H stretching \\
2920 and 2820 & C-H stretching \\
1747 and 1658 & alkyl ester carbonyls \\
1549 & C=C stretching \\
1458 and 1411 & H-C-H deformation \\
1053 & C-O stretching \\
997 & C-C stretching \\
845 & C-H out-of-plane bending \\
\hline
\end{tabular}

$\mathrm{OH}$ groups that pollen species contain and their hygroscopicity will be further discussed in Sect. 3.3.

\subsubsection{Infrared spectra of pollen samples at different RHs}

In situ DRIFTS was employed to explore the adsorption of water by pollen grains. Typical spectra of populous deltoides pollen as a function of RH up to $87 \%$, relative to that at $<1 \% \mathrm{RH}$, are displayed in Fig. 3. DRIFTS spectra of other pollen samples at different RHs can be found in Figs. S1-S5 in the Supplement and are very similar to those for populous deltoides pollen. As evident from Fig. 3, several IR peaks (e.g., 3593, 3205, 2135 and $1616 \mathrm{~cm}^{-1}$ ) appeared in the spectra at elevated $\mathrm{RH}$, when compared with that at $<1 \% \mathrm{RH}$, and their intensities increased with increasing RH. The peaks at 3205, 2135 and $1616 \mathrm{~cm}^{-1}$ can be assigned to the stretching, association and bending modes of adsorbed water (Goodman et al., 2001; Schuttlefield et al., 2007a; Ma et al., 2010; Hatch et al., 2011; Song and Boily, 2013; Yeşilbaş and Boily, 2016; Joshi et al., 2017; Ibrahim et al., 2018).

The peak at $\sim 3600 \mathrm{~cm}^{-1}$ was the most intensive one observed in the spectra, as shown in Fig. 3. For comparison, the IR peaks assigned to the stretching mode of adsorbed water on mineral dust and $\mathrm{NaCl}$ appeared at lower wave numbers, typically at around or lower than $3400 \mathrm{~cm}^{-1}$ (Schuttlefield et al., 2007a; Ma et al., 2010; Tang et al., 2016; Ibrahim et al., 2018). As a result, the peak at $\sim 3600 \mathrm{~cm}^{-1}$ may be assigned to the asymmetric stretching mode of water which interacted with $\mathrm{OH}$ groups in pollen samples (Iwamoto et al., 2003). These results imply that water adsorption by pollen samples could be mainly contributed to by $\mathrm{OH}$ groups of organic compounds they contained. Both $\mathrm{C}-\mathrm{OH}$ and $\mathrm{C}(\mathrm{O})-\mathrm{OH}$ groups can contribute to water adsorption by pollen samples, though their relative contribution cannot be resolved in our work. In addition, other factors, such as porosity and internal structure, may also be important for hygroscopic properties of pollen grains. The intensities of IR peaks at $\sim 3600 \mathrm{~cm}^{-1}$ were used to represent the amount of water adsorbed by pollen samples. Table 2 summarizes integrated areas of IR 


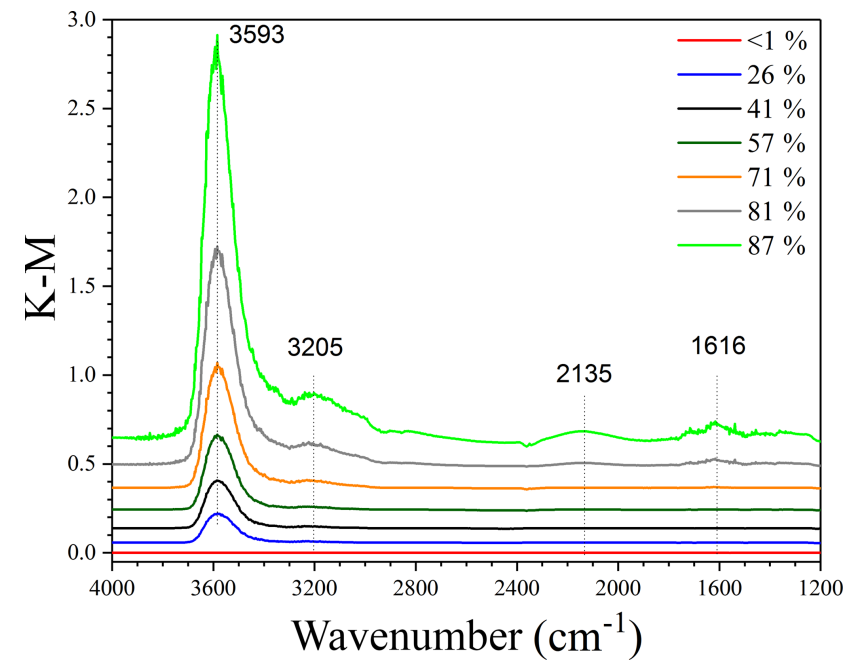

Figure 3. In situ DRIFTS spectra of populous deltoides pollen as a function of $\mathrm{RH}(<1 \%, 26 \%, 41 \%, 57 \%, 71 \%, 81 \%$ and $87 \%)$ at $25^{\circ} \mathrm{C}$.

Table 2. Integrated areas of IR peaks (at $\sim 3600 \mathrm{~cm}^{-1}$ ) of adsorbed water as a function of RH for the six pollen species investigated in this work. Wave number ranges used for integration are $3750-3300 \mathrm{~cm}^{-1}$ for Populus deltoides pollen, $3750-3350 \mathrm{~cm}^{-1}$ for Populus tremuloides pollen, $3750-3400 \mathrm{~cm}^{-1}$ for ragweed pollen, $3750-3500 \mathrm{~cm}^{-1}$ for corn pollen, $3750-3450 \mathrm{~cm}^{-1}$ for pecan pollen and $3750-3300 \mathrm{~cm}^{-1}$ for paper mulberry pollen.

\begin{tabular}{|c|c|c|c|c|c|}
\hline $\begin{array}{l}\text { RH } \\
(\%)\end{array}$ & $\begin{array}{r}\text { Peak } \\
\text { area }\end{array}$ & $\begin{array}{l}\mathrm{RH} \\
(\%)\end{array}$ & $\begin{array}{r}\text { Peak } \\
\text { area }\end{array}$ & $\begin{array}{l}\mathrm{RH} \\
(\%)\end{array}$ & $\begin{array}{r}\text { Peak } \\
\text { area }\end{array}$ \\
\hline \multicolumn{2}{|c|}{$\begin{array}{l}\text { Populus } \\
\text { deltoides }\end{array}$} & \multicolumn{2}{|c|}{$\begin{array}{l}\text { Populus } \\
\text { tremuloides }\end{array}$} & \multicolumn{2}{|c|}{ Ragweed } \\
\hline$<1$ & 0 & $<1$ & 0 & $<1$ & 0 \\
\hline 26 & 22.7 & 24 & 5.5 & 26 & 10.1 \\
\hline 41 & 36.9 & 41 & 16.4 & 42 & 18.9 \\
\hline 57 & 57.4 & 56 & 35.4 & 50 & 24.5 \\
\hline 71 & 93.6 & 70 & 66.5 & 56 & 30.2 \\
\hline 79 & 137.6 & 78 & 91.2 & 69 & 49.7 \\
\hline 81 & 164.7 & 87 & 156.9 & 88 & 104.6 \\
\hline 87 & 293.1 & & & & \\
\hline \multicolumn{2}{|c|}{ Corn } & \multicolumn{2}{|c|}{ Pecan } & \multicolumn{2}{|c|}{$\begin{array}{c}\text { Paper } \\
\text { mulberry }\end{array}$} \\
\hline$<1$ & 0 & $<1$ & 0 & $<1$ & 0 \\
\hline 26 & 10.0 & 26 & 8.6 & 26 & 10.2 \\
\hline 42 & 21.5 & 43 & 16.9 & 43 & 17.7 \\
\hline 58 & 41.9 & 58 & 29.5 & 51 & 23.1 \\
\hline 73 & 87.5 & 73 & 60.0 & 59 & 29.8 \\
\hline \multirow[t]{2}{*}{89} & 222.2 & 89 & 338.9 & 71 & 46.7 \\
\hline & & & & 86 & 105.1 \\
\hline
\end{tabular}

peaks at $3600 \mathrm{~cm}^{-1}$ as a function of $\mathrm{RH}$ for the six pollen species examined in our work, suggesting that the amount of adsorbed water by pollen samples increased with RH.

\subsection{Mass hygroscopic growth}

\subsubsection{Hygroscopicity parameterizations}

The single hygroscopicity parameter, $\kappa$, is widely used to describe the hygroscopicity of aerosol particles under both subsaturation and supersaturation (Petters and Kreidenweis, 2007). When the Kelvin effect is negligible (this is valid for pollen grains which are typically $>1 \mu \mathrm{m}$ ), the dependence of diameter-based growth factor (GF) on RH can be linked to $\kappa$ via Eq. (1) (Petters and Kreidenweis, 2007; Tang et al., 2016):

$\mathrm{RH}=\frac{\mathrm{GF}^{3}-1}{\mathrm{GF}^{3}-1+\kappa}$.

If we further assume that the particle is spherical, Eq. (1) can be transformed to Eq. (2):

$$
\begin{aligned}
\frac{1}{\mathrm{RH}} & =1+\frac{\kappa}{\mathrm{GF}^{3}-1}=1+\frac{\kappa}{\frac{V}{V_{0}}-1} \\
& =1+\kappa \frac{V_{0}}{V-V_{0}}=1+\kappa \frac{V_{0}}{V_{\mathrm{w}}},
\end{aligned}
$$

where $V, V_{0}$ and $V_{\mathrm{w}}$ are the volumes of the particle at the given $\mathrm{RH}$, the dry particle and water associated with the particle at the given RH. In order for Eq. (2) to be valid, it is also assumed that at a given RH, $V$ is equal to the sum of $V_{0}$ and $V_{\mathrm{w}}$. Equation (2) can be further transformed to Eqs. (3)-(4):

$$
\begin{aligned}
& \frac{1}{\mathrm{RH}}=1+\kappa \frac{\rho_{\mathrm{w}}}{\rho_{\mathrm{p}}} \frac{m_{0}}{m_{\mathrm{w}}} \\
& \frac{m_{\mathrm{w}}}{m_{0}}=\kappa \cdot \frac{\rho_{\mathrm{w}}}{\rho_{\mathrm{p}}} /\left(\frac{1}{\mathrm{RH}}-1\right),
\end{aligned}
$$

where $\rho_{\mathrm{w}}$ and $\rho_{\mathrm{p}}$ are the density of water and the dry particle, and $m_{0}$ and $m_{\mathrm{w}}$ are the mass of the dry particle and water associated with the particle at the given RH. Since the particle mass, $m$, is equal to the sum of $m_{0}$ and $m_{\mathrm{w}}$, Eq. (5) can be derived from Eq. (4):

$\frac{m}{m_{0}}=1+\kappa \frac{\rho_{\mathrm{w}}}{\rho_{\mathrm{p}}} /\left(\frac{1}{\mathrm{RH}}-1\right)$.

Using an electrodynamic balance, Pope (2010) and Griffiths et al. (2012) measured hygroscopic growth of eight types of pollen grains and found that their mass change with $\mathrm{RH}$ can be approximated by Eq. (5). It should be noted that the original equation derived by Pope (2010) and Griffiths et al. (2012) has a different format from but is essentially equivalent to Eq. (5). Equation (5) relates mass growth experimentally measured in our work to the single hygroscopicity parameter $(\kappa)$, which has been widely used in atmospheric science to describe hygroscopic properties of aerosol particles 
under subsaturation as well as their $\mathrm{CCN}$ activities under supersaturation; nevertheless, a few assumptions are needed to derive Eq. (5), as discussed.

The Freundlich adsorption isotherm is another widely used equation that describes the change in sample mass with $\mathrm{RH}$ due to water uptake (Atkins, 1998; Skopp, 2009; Hatch et al., 2011; Tang et al., 2016):

$\frac{m}{m_{0}}=1+A_{\mathrm{f}} \cdot \sqrt[B_{\mathrm{f}}]{\mathrm{RH}}$,

where $A_{\mathrm{f}}$ and $B_{\mathrm{f}}$ are empirical Freundlich constants related to the adsorption capacity and strength. One advantage of the Freundlich adsorption isotherm is that it provides a direct relationship between RH and mass growth, which was experimentally measured in our work, without any additional assumptions. In addition, the BET (Brunauer-Emmett-Teller) adsorption isotherm is also widely used to describe water adsorption by insoluble solid particles (Brunauer et al., 1938; Goodman et al., 2001; Henson, 2007; Ma et al., 2010; Tang et al., 2016; Joshi et al., 2017). While the BET adsorption isotherm typically works well for water adsorption of a few monolayers, the mass of adsorbed water, as shown in Sect. 3.2.2, can reach up to $50 \%$ of the dry pollen mass at high RH; therefore, in this work we did not attempt to use the BET adsorption isotherm to describe water adsorption by pollen grains. Another reason that we did not attempt to use the BET adsorption isotherm is that the BET adsorption isotherm is mathematically more complex and requires the BET surface area to be known.

\subsubsection{Mass hygroscopic growth at room temperature}

Figure 4 displays the sample mass (normalized to that at $0 \% \mathrm{RH})$ as a function of $\mathrm{RH}$ for pecan pollen at $25^{\circ} \mathrm{C}$. A significant increase in sample mass was observed at elevated $\mathrm{RH}$ due to uptake of water. Compared to that at $<1 \% \mathrm{RH}$, the sample mass increased by $(2.3 \pm 0.3) \%$ at $30 \% \mathrm{RH}$, $(6.4 \pm 0.2) \%$ at $60 \% \mathrm{RH},(30.3 \pm 0.4) \%$ at $90 \% \mathrm{RH}$, and up to $\sim 72 \%$ at $95 \% \mathrm{RH}$. As shown by the data compiled in Tables S1-S3 in the Supplement, substantial increases in sample mass were also observed for the other five types of pollen species at $25^{\circ} \mathrm{C}$ (as well as 5 and $37^{\circ} \mathrm{C}$ ).

Hygroscopic properties exhibited considerable variations among different pollen species. Figure 5a compares the measured ratios of sample mass at $90 \% \mathrm{RH}$ to that at $<1 \% \mathrm{RH}$, $m(90 \%) / m_{0}$, for the six pollen species investigated in this work. We specifically discuss mass changes of pollen grains at $90 \% \mathrm{RH}$ (relative to that at $<1 \% \mathrm{RH}$ ) because aerosol hygroscopic growth at $90 \% \mathrm{RH}$ was widely reported by laboratory and field studies (Kreidenweis and Asa-Awuku, 2014). As shown in Fig. 5a, $m(90 \%) / m_{0}$ determined at $25^{\circ} \mathrm{C}$ ranged from $1.293 \pm 0.028$ (ragweed pollen) to $1.476 \pm 0.094$ (Populus deltoides pollen); i.e., the amount of water adsorbed or absorbed by the six different pollen species at $90 \% \mathrm{RH}$ varied between $\sim 30 \%$ to $\sim 50 \%$ of the dry mass.

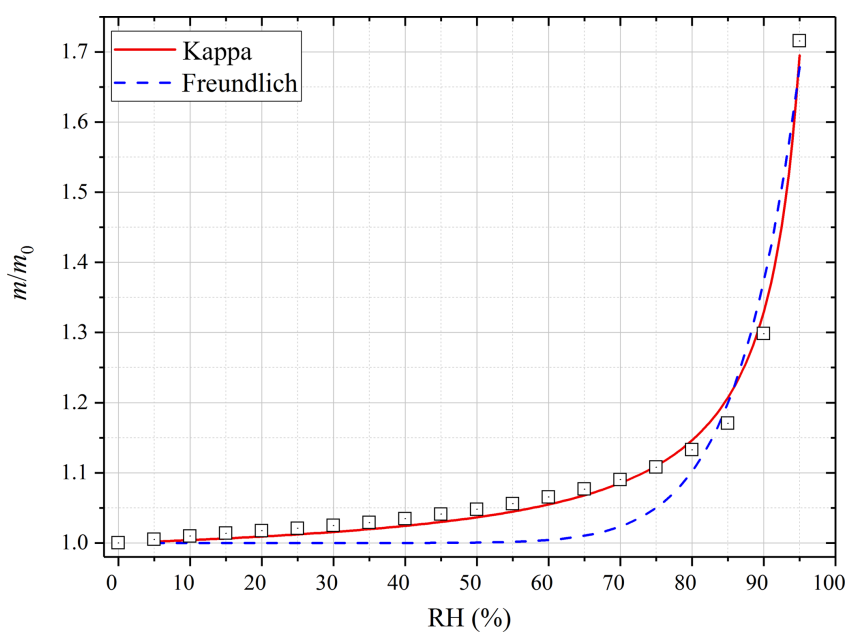

Figure 4. Measured change in sample mass (normalized to that at dry conditions, i.e., $m / m_{0}$ ) of pecan pollen as a function of $\mathrm{RH}$ $(0 \%-95 \%)$ at $25^{\circ} \mathrm{C}$. The experimental data are fitted with the modified $\kappa$-Köhler equation (solid red curve) and the Freundlich adsorption isotherm (dashed blue curve).

As shown in Fig. 4, the increase in pecan pollen mass with $\mathrm{RH}$ at $25^{\circ} \mathrm{C}$ could be satisfactorily described by the modified $\kappa$-Köhler equation for the entire RH range (up to $95 \%$ ). On the contrary, the Freundlich adsorption isotherm significantly underestimated the sample mass at low RH, although it represented the experimental data at high $\mathrm{RH}$ reasonably well. In addition, we found that the modified $\kappa$-Köhler equation could also approximate the dependence of sample mass on RH for all the six types of pollen species investigated in this work at different temperatures. If we use Eq. (5) to fit $m / m_{0}$ against RH, $\kappa \cdot \rho_{\mathrm{w}} / \rho_{\mathrm{p}}$ can be derived. The bulk densities of dry pollen grains were found to vary with species but typically fall into the range of $0.5-2 \mathrm{~g} \mathrm{~cm}^{-3}$ (Harrington and Metzger, 1963; Hirose and Osada, 2016), and for simplicity $\rho_{\mathrm{p}}$ was assumed to be $1 \mathrm{~g} \mathrm{~cm}^{-3}$ in this work (i.e., $\rho_{\mathrm{w}} / \rho_{\mathrm{p}}$ is equal to 1 ). With the assumptions on dry particle density and also particle sphericity, $\kappa$ could then be derived from the measured RH-dependent sample mass at a given temperature.

Table 3 summarizes the average $\kappa$ values at different temperatures for the six pollen species investigated in this work. At $25^{\circ} \mathrm{C}$, the $\kappa$ values were found to increase from $0.034 \pm 0.001$ for ragweed pollen to $0.061 \pm 0.007$ for Рориlus tremuloides pollen, varied by almost a factor of 2 . The $\kappa$ values measured by Pope and co-workers (Pope, 2010; Griffiths et al., 2012) were approximately in the range of 0.050.11 (assuming that $\rho_{\mathrm{w}} / \rho_{\mathrm{p}}$ is equal to 1 ), in reasonably good agreement with these reported in our work. It should be noted that, in order to convert the measured mass growth to diameter growth and $\kappa$ values, one key assumption is particle sphericity; nevertheless, pollen grains are known to be nonspherical and porous, and therefore our derived $\kappa$ val- 

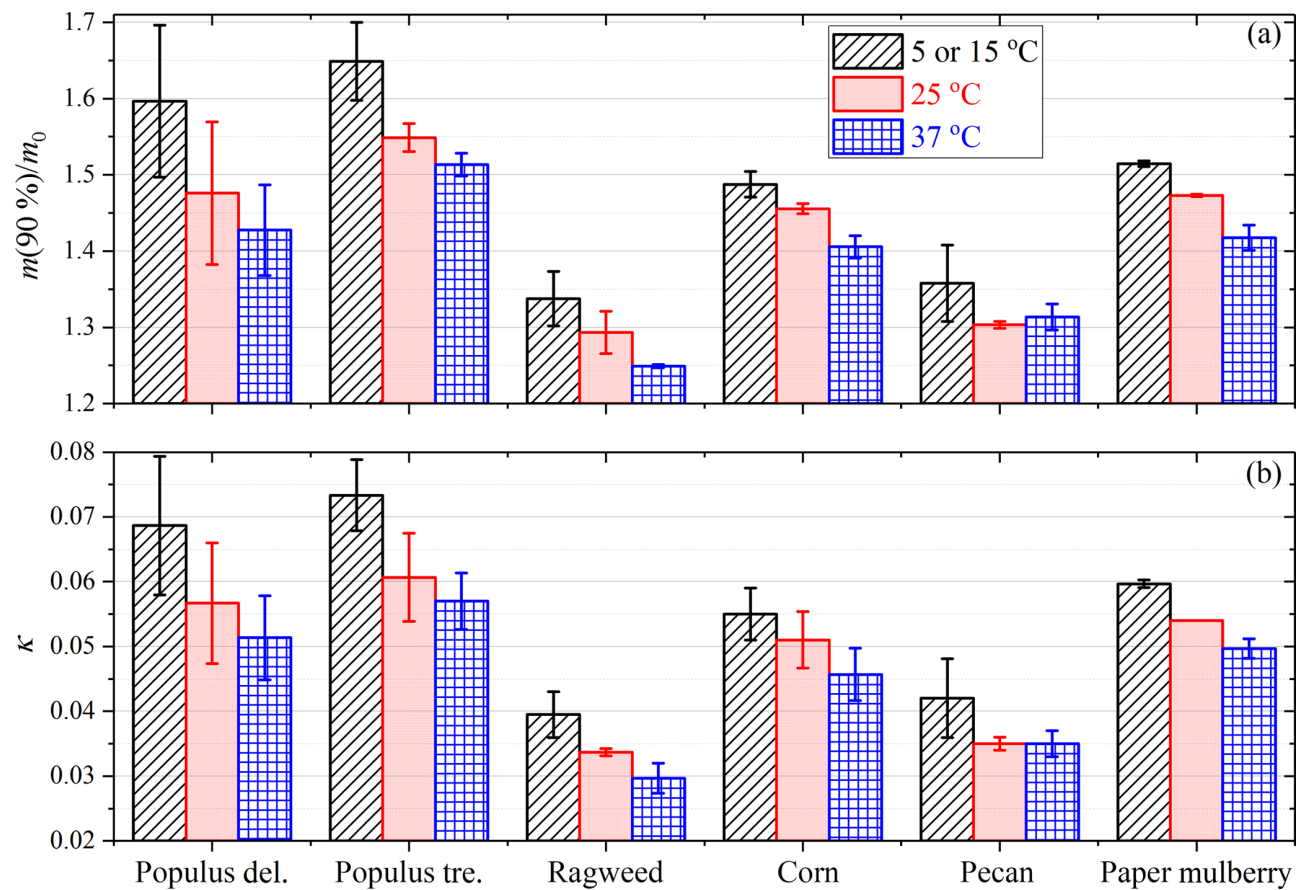

Figure 5. Measured ratios of sample mass at $90 \% \mathrm{RH}$ to that at $<1 \% \mathrm{RH}$ (a) and derived $\kappa$ values (b) for six pollen species at different temperatures. The lowest temperatures were $5{ }^{\circ} \mathrm{C}$ for Populus deltoides (P. deltoides), Populus tremuloides (P. tremuloides) and ragweed pollen, and $15^{\circ} \mathrm{C}$ for corn, pecan and paper mulberry pollen.

Table 3. Single hygroscopicity parameters $(\kappa)$ derived in this work for the six pollen species at different temperatures. All the errors given in this work are standard deviations.

\begin{tabular}{lrrrrr}
\hline Pollen type & $T\left({ }^{\circ} \mathrm{C}\right)$ & Sample 1 & Sample 2 & Sample 3 & average \\
\hline Populus & 5 & $0.071 \pm 0.001$ & $0.078 \pm 0.001$ & $0.057 \pm 0.002$ & $0.069 \pm 0.011$ \\
deltoides & 25 & $0.054 \pm 0.001$ & $0.067 \pm 0.002$ & $0.049 \pm 0.002$ & $0.057 \pm 0.009$ \\
& 37 & $0.058 \pm 0.002$ & $0.051 \pm 0.001$ & $0.045 \pm 0.002$ & $0.051 \pm 0.007$ \\
\hline Populus & 5 & $0.068 \pm 0.001$ & $0.073 \pm 0.001$ & $0.079 \pm 0.001$ & $0.073 \pm 0.006$ \\
tremuloides & 25 & $0.053 \pm 0.002$ & $0.063 \pm 0.002$ & $0.066 \pm 0.002$ & $0.061 \pm 0.007$ \\
& 37 & $0.052 \pm 0.002$ & $0.059 \pm 0.002$ & $0.060 \pm 0.002$ & $0.057 \pm 0.004$ \\
\hline Ragweed & 5 & $0.042 \pm 0.001$ & $0.037 \pm 0.002$ & & - \\
& 25 & $0.033 \pm 0.002$ & $0.034 \pm 0.003$ & $0.034 \pm 0.002$ & $0.034 \pm 0.001$ \\
& 37 & $0.027 \pm 0.001$ & $0.031 \pm 0.002$ & $0.031 \pm 0.002$ & $0.030 \pm 0.002$ \\
\hline Corn & 15 & $0.051 \pm 0.001$ & $0.059 \pm 0.002$ & $0.055 \pm 0.002$ & $0.055 \pm 0.004$ \\
& 25 & $0.046 \pm 0.002$ & $0.053 \pm 0.002$ & $0.054 \pm 0.002$ & $0.051 \pm 0.004$ \\
& 37 & $0.041 \pm 0.002$ & $0.048 \pm 0.002$ & $0.048 \pm 0.002$ & $0.046 \pm 0.004$ \\
\hline Pecan & 15 & $0.049 \pm 0.001$ & $0.038 \pm 0.001$ & $0.039 \pm 0.001$ & $0.042 \pm 0.006$ \\
& 25 & $0.036 \pm 0.001$ & $0.034 \pm 0.001$ & $0.035 \pm 0.001$ & $0.035 \pm 0.001$ \\
& 37 & $0.033 \pm 0.001$ & $0.035 \pm 0.002$ & $0.037 \pm 0.001$ & $0.035 \pm 0.002$ \\
\hline Paper & 15 & $0.059 \pm 0.002$ & $0.060 \pm 0.002$ & $0.060 \pm 0.002$ & $0.060 \pm 0.001$ \\
mulberry & 25 & $0.054 \pm 0.001$ & $0.054 \pm 0.001$ & $0.054 \pm 0.001$ & $0.054 \pm 0.001$ \\
& 37 & $0.048 \pm 0.002$ & $0.050 \pm 0.002$ & $0.051 \pm 0.002$ & $0.050 \pm 0.002$ \\
\hline
\end{tabular}



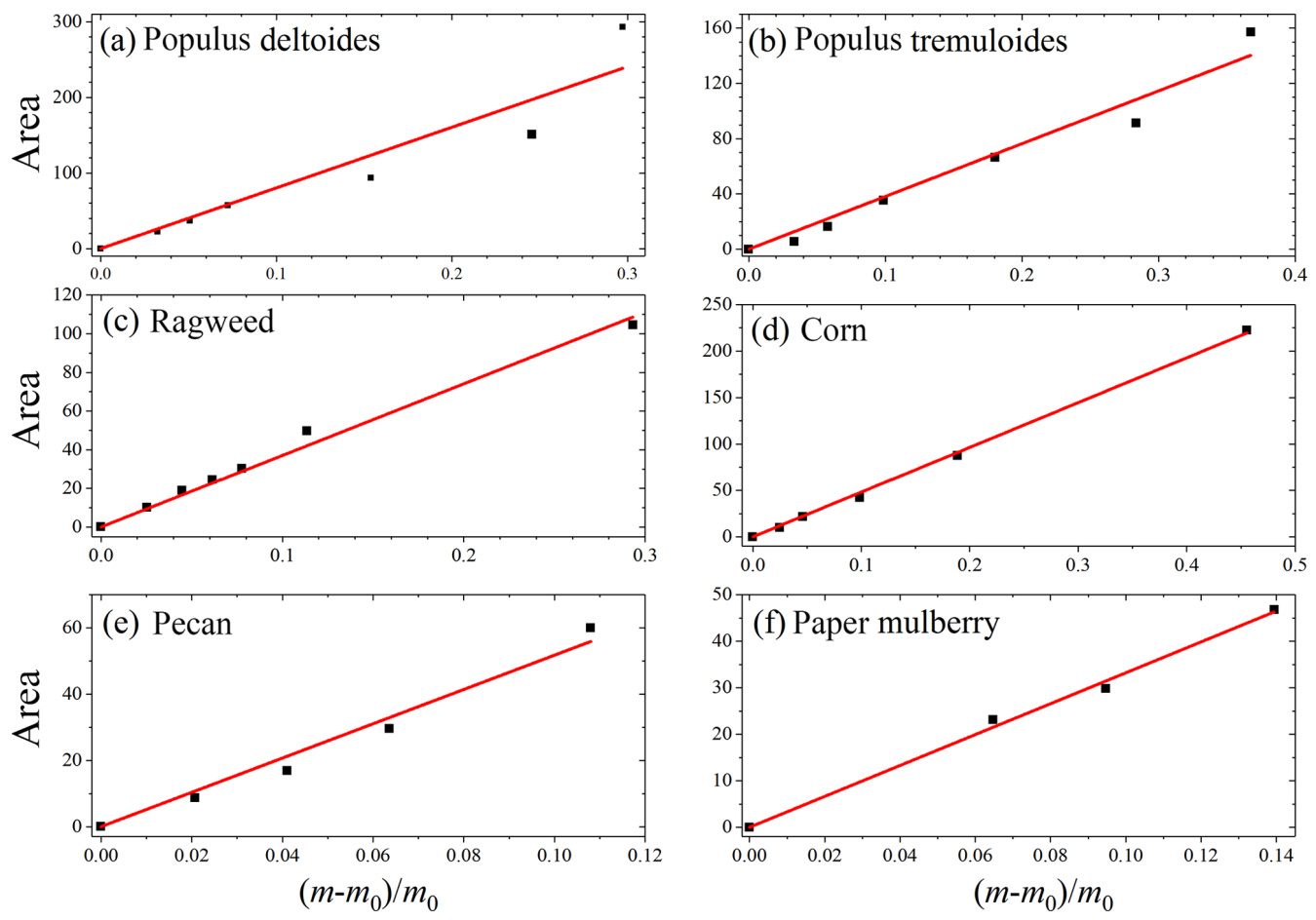

Figure 6. Integrated areas of IR peaks at $\sim 3600 \mathrm{~cm}^{-1}$ vs. relative mass increase due to water uptake, $\left(m-m_{0}\right) / m_{0}$, for six pollen species: (a) Populus deltoides, (b) Populus tremuloides, (c) ragweed, (d) corn, (e) pecan and (f) paper mulberry.

ues might be smaller than the actual values. For example, although the mass increase was substantial (around 30\%$50 \%$ at $90 \% \mathrm{RH}$ ) for the six pollen species examined, their $\kappa$ values at $25^{\circ} \mathrm{C}$ were derived to be in the range of 0.034 0.061 , significantly smaller than those $(0.1-0.2)$ for typical secondary organic aerosols produced in smog chamber studies (Petters and Kreidenweis, 2007; Kreidenweis and AsaAwuku, 2014).

\subsection{Discussion}

\subsubsection{Reconciliation between IR and VSA results}

Our in situ DRIFTS measurements, discussed in Sect. 3.1.2, suggested that water uptake by pollen samples was mainly contributed to by $\mathrm{OH}$ groups of organic compounds they contained; therefore, one may expect that pollen species which contain higher levels of $\mathrm{OH}$ groups would exhibit higher hygroscopicity. Transmission FTIR characterization of pollen species (Sect. 3.1.1) showed that Populus deltoides, Populus tremuloides and paper mulberry pollen contained relatively high levels of $\mathrm{OH}$ groups, and indeed their hygroscopicity ( $\kappa$ : $0.053-0.054$ at $25^{\circ} \mathrm{C}$ ) was higher than the other three pollen species, as shown in Fig. 5 and Table 3. For comparison, ragweed and pecan pollen contained relatively low levels of $\mathrm{OH}$ groups and correspondingly exhibited lower hygroscopicity $\left(\kappa: 0.033-0.036\right.$ at $\left.25^{\circ} \mathrm{C}\right)$. Corn pollen appeared to be an exception: it contained relatively low levels of $\mathrm{OH}$ groups but displayed medium hygroscopicity $(\kappa: \sim 0.046$ at $25^{\circ} \mathrm{C}$ ). As a result, our results may imply that, in addition to chemical composition, other physicochemical properties, such as porosity and internal structure of pollen grains, could also play an important role in determining the hygroscopicity of pollen species. One clue came from environmental scanning electron microscopy observations (Pope, 2010), revealing that pollen grains started to swell internally before significant water uptake on the surface took place.

In our work two complementary techniques were employed to explore hygroscopic properties of pollen species. VSA measured the amount of water absorbed/adsorbed by pollen grains as a function of $\mathrm{RH}$ in a quantitative manner, whereas the intensities of IR peaks of adsorbed water at different RHs, as characterized by DRIFTS, can be used semiquantitatively to represent the amount of water associated with particles (Goodman et al., 2001; Schuttlefield et al., 2007b; Ma et al., 2010; Yeşilbaş and Boily, 2016; Joshi et al., 2017; Ibrahim et al., 2018). We compare our VSA results (i.e., the relative mass change due to water uptake) to the DRIFTS results (i.e., integrated area of IR peaks at $\sim 3600 \mathrm{~cm}^{-1}$ ). As shown in Fig. 6, good correlations between VSA and DRIFTS results are found for all the six pollen species, suggesting that DRIFTS can be used to represent the amount of adsorbed water, at least in a semiquantitative manner. 


\subsubsection{Effect of temperature}

Figure 5a shows the comparison of the measured ratios of sample mass at $90 \% \mathrm{RH}$ to that at $<1 \% \mathrm{RH}, m(90 \%) / m_{0}$, at different temperatures for the six pollen species. It can be concluded from Fig. 5a that, except for pecan pollen, for which a small increase in $m(90 \%) / m_{0}$ occurred when temperature increased from 25 to $37^{\circ} \mathrm{C}$, an increase in temperature would lead to a small but nevertheless significant decrease in $m(90 \%) / m_{0}$. For example, $m(90 \%) / m_{0}$ decreased from $1.597 \pm 0.100$ at $5^{\circ} \mathrm{C}$ to $1.476 \pm 0.094$ at $25^{\circ} \mathrm{C}$ and to $1.427 \pm 0.060$ at $37^{\circ} \mathrm{C}$ for Populus deltoides pollen, and from $1.338 \pm 0.036$ at $5^{\circ} \mathrm{C}$ to $1.293 \pm 0.028$ at $25^{\circ} \mathrm{C}$ and to $1.249 \pm 0.002$ at $37^{\circ} \mathrm{C}$ for ragweed pollen.

We further derived $\kappa$ values at different temperatures for the six pollen species, and the results are plotted in Fig. 5b and summarized in Table 3. An increase in temperature would lead to a decrease in $\kappa$ values, except for pecan pollen. For example, $\kappa$ decreased from $0.073 \pm 0.006$ at $5^{\circ} \mathrm{C}$ to $0.057 \pm 0.004$ at $37^{\circ} \mathrm{C}$ for Populus tremuloides pollen, and decreased from $0.060 \pm 0.001$ at $15^{\circ} \mathrm{C}$ to $0.050 \pm 0.002$ at $37^{\circ} \mathrm{C}$ for paper mulberry pollen.

\section{Conclusion and implications}

Pollen grains are one of the most abundant types of primary biological aerosol particles in the troposphere and play important roles in many aspects of the Earth's system. Hygroscopicity is among the most important physicochemical properties of pollen grains and largely affects their environmental, health and climatic impacts. However, our knowledge of their hygroscopicity is still quite limited, and the temperature effect in particular has been rarely explored.

In this work we investigated hygroscopic properties of six types of pollen species as a function of $\mathrm{RH}$ (up to $95 \%$ ) at 5 (or 15), 25 and $37^{\circ} \mathrm{C}$. A substantial increase in pollen mass was observed at elevated RH due to water uptake for all the six pollen species. Therefore, a change in the mass of pollen grains and their aerodynamic properties at different RHs should be taken into account to better understand their transport and deposition in the troposphere. It was found that the mass hygroscopic growth of pollen grains can be well approximated by the modified $\kappa$-Köhler equation. The derived $\kappa$ values at $25^{\circ} \mathrm{C}$ ranged from $0.034 \pm 0.001$ to $0.061 \pm 0.007$, varying with pollen species. DRIFTS measurements indicated that water adsorption by pollen species were mainly contributed to by $\mathrm{OH}$ groups of organic compounds contained by pollen grains, and indeed pollen species that contained lower levels of $\mathrm{OH}$ groups (relative to $\mathrm{C}-\mathrm{H}$ groups, as determined using transmission FTIR) showed lower hygroscopicity. One exception was corn pollen, which contained low levels of $\mathrm{OH}$ group but exhibited medium hygroscopicity, suggesting that, in addition to chemical composition, other physicochemical properties, such as porosity and inter- nal structure, might also play an important role in determining the hygroscopicity of pollen grains. Due to their moderate hygroscopicity as well as large sizes, pollen grains can thus act as efficient giant $\mathrm{CCN}$, which may have significant impacts on cloud and precipitation (Johnson, 1982; Feingold et al., 1999; Yin et al., 2000; Posselt and Lohmann, 2008). It is worth noting that only six different pollen species were examined in our work, and hygroscopic properties of other pollen species commonly found in the troposphere should be further investigated.

The effect of temperature on the hygroscopicity of pollen grains was systematically investigated in this work. An increase in temperature (from 5 or 15 to 25 and $37^{\circ} \mathrm{C}$ ), in a range from chilling temperatures to physiological temperatures, led to a small but detectable decrease in pollen hygroscopicity. For example, $\kappa$ values were found to decrease from $0.073 \pm 0.006$ at $5^{\circ} \mathrm{C}$ to $0.061 \pm 0.007$ at $25^{\circ} \mathrm{C}$ and to $0.057 \pm 0.004$ at $37^{\circ} \mathrm{C}$ for Populus tremuloides pollen, and decrease from $0.060 \pm 0.001$ at $15^{\circ} \mathrm{C}$ to $0.054 \pm 0.001$ at $25^{\circ} \mathrm{C}$ to $0.050 \pm 0.002$ at $37^{\circ} \mathrm{C}$ for paper mulberry pollen. Our measurements at $37^{\circ} \mathrm{C}$ (physiological temperature) provide very valuable parameters which can be used in numerical models to better understand the transport and deposition of pollen particles in the respiratory system and thus their impacts on human health (Yeh et al., 1996; Broday and Georgopoulos, 2001; Park and Wexler, 2008; Lambert et al., 2011; Longest and Holbrook, 2012; Tong et al., 2014). Nevertheless, it should be noted that, due to the short residence time in the respiratory system, pollen grains and other inhaled particles in general may not reach equilibrium with water vapor in the respiratory tract.

Due to technical challenges, the lowest temperature we could reach in this work was $5^{\circ} \mathrm{C}$, in the range of normal chilling temperatures for vegetative species, and also in the expected temperature range at the altitudes of $0.5-2.0 \mathrm{~km}$ to which pollen grains can be easily transported. Temperatures in the upper troposphere can be as low as below $-70^{\circ} \mathrm{C}$, and it is yet to be explored whether a further decrease in temperature to far below $0{ }^{\circ} \mathrm{C}$ will lead to a large increase in pollen hygroscopicity. As a result, experimental measurements of pollen hygroscopicity at lower temperatures are warranted and would significantly help to better understand the transport of pollen grains in the troposphere. Since water vapor has to be adsorbed or condensed on ice-nucleating particles before heterogeneous ice nucleation can take place (Laaksonen et al., 2016), knowledge of hygroscopicity and water uptake at temperatures below $0{ }^{\circ} \mathrm{C}$ would provide fundamental insights into atmospheric ice nucleation, in which pollen grains may play an important role (Pratt et al., 2009; Prenni et al., 2009; Hoose et al., 2010; Pöschl et al., 2010; Murray et al., 2012; Creamean et al., 2013; Tang et al., 2018).

Data availability. All the data are available from Mingjin Tang (mingjintang@gig.ac.cn) on request. 
Supplement. The supplement related to this article is available online at: https://doi.org/10.5194/acp-19-2247-2019-supplement.

Author contributions. MT, QM and YJL designed the research; WG, CZ, SL and XY took the measurements; MT, QM, YJL and RJH analyzed the results; MT, QM, YJL and RJH wrote the manuscript with contributions from all the co-authors.

Competing interests. The authors declare that they have no conflict of interest.

Special issue statement. This article is part of the special issue "Multiphase chemistry of secondary aerosol formation under severe haze". It is not associated with a conference.

Acknowledgements. This work was funded by National Natural Science Foundation of China (91644106, 91744204 and 91644219), Chinese Academy of Sciences (132744KYSB20160036), Science and Technology Development Fund of Macau (016/2017/A1), and State Key Laboratory of Organic Geochemistry (SKLOG2016A05). Mingjin Tang would like to thank the CAS Pioneer Hundred Talents program for providing a starting grant. This is contribution no. IS-2661 from GIGCAS.

Edited by: Jingkun Jiang

Reviewed by: two anonymous referees

\section{References}

Ariya, P. A., Sun, J., Eltouny, N. A., Hudson, E. D., Hayes, C. T., and Kos, G.: Physical and chemical characterization of bioaerosols - Implications for nucleation processes, Int. Rev. Phys. Chem., 28, 1-32, 2009.

Asad, A., Mmereki, B. T., and Donaldson, D. J.: Enhanced uptake of water by oxidatively processed oleic acid, Atmos. Chem. Phys., 4, 2083-2089, https://doi.org/10.5194/acp-4-2083-2004, 2004.

Atkins, P. W.: Physical Chemistry, 6th Edn., Oxford University Press, Oxford, UK, 1998.

Bauer, H., Giebl, H., Hitzenberger, R., Kasper-Giebl, A., Reischl, G., Zibuschka, F., and Puxbaum, H.: Airborne bacteria as cloud condensation nuclei, J. Geophys. Res.-Atmos, 108, 4658, https://doi.org/10.1029/2003JD003545, 2003.

Broday, D. M. and Georgopoulos, P. G.: Growth and Deposition of Hygroscopic Particulate Matter in the Human Lungs, Aerosol Sci. Tech., 34, 144-159, 2001.

Brunauer, S., Emmett, P. H., and Teller, E.: Adsorption of Gases in Multimolecular Layers, J. Am. Chem. Soc., 60, 309-319, 1938.

Bunderson, L. D. and Levetin, E.: Hygroscopic weight gain of pollen grains from Juniperus species, Int. J. Biometeorol., 59, 533-540, 2015.

Creamean, J. M., Suski, K. J., Rosenfeld, D., Cazorla, A., DeMott, P. J., Sullivan, R. C., White, A. B., Ralph, F. M., Minnis, P., Comstock, J. M., Tomlinson, J. M., and Prather, K. A.: Dust and Bi- ological Aerosols from the Sahara and Asia Influence Precipitation in the Western U.S., Science, 339, 1572-1578, 2013.

Deguillaume, L., Leriche, M., Amato, P., Ariya, P. A., Delort, A.M., Pöschl, U., Chaumerliac, N., Bauer, H., Flossmann, A. I., and Morris, C. E.: Microbiology and atmospheric processes: chemical interactions of primary biological aerosols, Biogeosciences, 5, 1073-1084, https://doi.org/10.5194/bg-5-1073-2008, 2008.

Després, V. R., Huffman, J. A., Burrows, S. M., Hoose, C., Safatov, A. S., Buryak, G., Fröhlich-Nowoisky, J., Elbert, W., Andreae, M. O., Pöschl, U., and Jaenicke, R.: Primary biological aerosol particles in the atmosphere: a review, Tellus B, 64, 15598, https://doi.org/10.3402/tellusb.v64i0.15598, 2012.

Diehl, K., Quick, C., Matthias-Maser, S., Mitra, S. K., and Jaenicke, R.: The ice nucleating ability of pollen - Part I: Laboratory studies in deposition and condensation freezing modes, Atmos. Res., 58, 75-87, 2001.

Douwes, J., Thorne, P., Pearce, N., and Heederik, D.: Bioaerosol health effects and exposure assessment: Progress and prospects, Ann. Occup. Hyg., 47, 187-200, 2003.

Eliason, T. L., Aloisio, S., Donaldson, D. J., Cziczo, D. J., and Vaida, V.: Processing of unsaturated organic acid films and aerosols by ozone, Atmos. Environ., 37, 2207-2219, 2003.

Estillore, A. D., Trueblood, J. V., and Grassian, V. H.: Atmospheric chemistry of bioaerosols: heterogeneous and multiphase reactions with atmospheric oxidants and other trace gases, Chem. Sci., 7, 6604-6616, 2016.

Feingold, G., Cotton, W. R., Kreidenweis, S. M., and Davis, J. T.: The Impact of Giant Cloud Condensation Nuclei on Drizzle Formation in Stratocumulus: Implications for Cloud Radiative Properties, J. Atmos. Sci., 56, 4100-4117, 1999.

Fröhlich-Nowoisky, J., Kampf, C. J., Weber, B., Huffman, J. A., Pöhlker, C., Andreae, M. O., Lang-Yona, N., Burrows, S. M., Gunthe, S. S., Elbert, W., Su, H., Hoor, P., Thines, E., Hoffmann, T., Després, V. R., and Pöschl, U.: Bioaerosols in the Earth system: Climate, health, and ecosystem interactions, Atmos. Res., 182, 346-376, 2016.

Franc, G. D. and DeMott, P. J.: Cloud activation characteristics of airborne Erwinia carotovora cells, J. Appl. Meteorol., 37, 12931300, 1998.

Georgakopoulos, D. G., Després, V., Fröhlich-Nowoisky, J., Psenner, R., Ariya, P. A., Pósfai, M., Ahern, H. E., Moffett, B. F., and Hill, T. C. J.: Microbiology and atmospheric processes: biological, physical and chemical characterization of aerosol particles, Biogeosciences, 6, 721-737, https://doi.org/10.5194/bg-6721-2009, 2009.

Goodman, A. L., Bernard, E. T., and Grassian, V. H.: Spectroscopic Study of Nitric Acid and Water Adsorption on Oxide Particles: Enhanced Nitric Acid Uptake Kinetics in the Presence of Adsorbed Water, J. Phys. Chem. A, 105, 6443-6457, 2001.

Griffiths, P. T., Borlace, J. S., Gallimore, P. J., Kalberer, M., Herzog, M., and Pope, F. D.: Hygroscopic growth and cloud activation of pollen: a laboratory and modelling study, Atmos. Sci. Lett., 13, 289-295, 2012.

Gu, W., Li, Y., Zhu, J., Jia, X., Lin, Q., Zhang, G., Ding, X., Song, W., Bi, X., Wang, X., and Tang, M.: Investigation of water adsorption and hygroscopicity of atmospherically relevant particles using a commercial vapor sorption analyzer, Atmos. Meas. Tech., 10, 3821-3832, https://doi.org/10.5194/amt10-3821-2017, 2017. 
Guo, L., Gu, W., Peng, C., Wang, W., Li, Y. J., Zong, T., Tang, Y., Wu, Z., Lin, Q., Ge, M., Zhang, G., Hu, M., Bi, X., Wang, X., and Tang, M.: A comprehensive study of hygroscopic properties of calcium- and magnesium-containing salts: implication for hygroscopicity of mineral dust and sea salt aerosols, Atmos. Chem. Phys., 19, 2115-2133, https://doi.org/10.5194/acp19-2115-2019, 2019.

Gute, E. and Abbatt, J. P. D.: Oxidative Processing Lowers the Ice Nucleation Activity of Birch and Alder Pollen, Geophys. Res. Lett., 45, 1647-1653, 2018.

Harrington, J. B. and Metzger, K.: Ragweed Pollen Density, Am. J. Bot., 50, 532-539, 1963.

Hatch, C. D., Wiese, J. S., Crane, C. C., Harris, K. J., Kloss, H. G., and Baltrusaitis, J.: Water Adsorption on Clay Minerals As a Function of Relative Humidity: Application of BET and Freundlich Adsorption Models, Langmuir, 28, 1790-1803, 2011.

Henson, B. F.: An adsorption model of insoluble particle activation: Application to black carbon, J. Geophys. Res.-Atmos., 112, D24S16, https://doi.org/10.1029/2007JD008549, 2007.

Hirose, Y. and Osada, K.: Terminal settling velocity and physical properties of pollen grains in still air, Aerobiologia, 32, 385-394, 2016.

Hoose, C., Kristjansson, J. E., and Burrows, S. M.: How important is biological ice nucleation in clouds on a global scale?, Environ. Res. Lett., 5, 024009, https://doi.org/10.1088/17489326/5/2/024009, 2010.

Hung, H. M., Katrib, Y., and Martin, S. T.: Products and mechanisms of the reaction of oleic acid with ozone and nitrate radical, J. Phys. Chem. A, 109, 4517-4530, 2005.

Ibrahim, S., Romanias, M. N., Alleman, L. Y., Zeineddine, M. N., Angeli, G. K., Trikalitis, P. N., and Thevenet, F.: Water Interaction with Mineral Dust Aerosol: Particle Size and Hygroscopic Properties of Dust, ACS Earth and Space Chem., 2, 376-386, 2018.

International Grains Council: Grain Market Report GMR 495, 2019.

Iwamoto, R., Matsuda, T., Sasaki, T., and Kusanagi, H.: Basic interactions of water with organic compounds, J. Phys. Chem. B, 107, 7976-7980, 2003.

Jia, X. H., Gu, W. J., Li, Y. J., Cheng, P., Tang, Y. J., Guo, L. Y., Wang, X. M., and Tang, M. J.: Phase transitions and hygroscopic growth of $\mathrm{Mg}\left(\mathrm{ClO}_{4}\right)_{2}, \mathrm{NaClO}_{4}$, and $\mathrm{NaClO}_{4} \cdot \mathrm{H}_{2} \mathrm{O}$ : implications for the stability of aqueous water in hyperarid environments on Mars and on Earth, ACS Earth Space Chem., 2, 159-167, 2018.

Johnson, D. B.: The Role of Giant and Ultragiant Aerosol Particles in Warm Rain Initiation, J. Atmos. Sci., 39, 448-460, 1982.

Joshi, N., Romanias, M. N., Riffault, V., and Thevenet, F.: Investigating water adsorption onto natural mineral dust particles: Linking DRIFTS experiments and BET theory, Aeolian Res., 27, 3545, 2017.

Ko, G., First, M. W., and Burge, H. A.: Influence of relative humidity on particle size and UV sensitivity of Serratia marcescens and Mycobacterium bovis BCG aerosols, Tubercle Lung Dis., 80, 217-228, 2000.

Kreidenweis, S. M. and Asa-Awuku, A.: 5.13 - Aerosol Hygroscopicity: Particle Water Content and Its Role in Atmospheric Processes, in: Treatise on Geochemistry, edited by: Turekian, K. K., 2nd Edn., Elsevier, Oxford, 331-361, 2014.
Laaksonen, A., Malila, J., Nenes, A., Hung, H. M., and Chen, J. P.: Surface fractal dimension, water adsorption efficiency, and cloud nucleation activity of insoluble aerosol, Sci. Rep.-UK, 6, 25504, https://doi.org/10.1038/srep25504, 2016.

Lambert, A. R., O'Shaughnessy, P. T., Tawhai, M. H., Hoffman, E. A., and Lin, C. L.: Regional Deposition of Particles in an Image-Based Airway Model: Large-Eddy Simulation and LeftRight Lung Ventilation Asymmetry, Aerosol Sci. Tech., 45, 11 25, 2011.

Lee, B. U., Kim, S. H., and Kim, S. S.: Hygroscopic growth of Ecoli and B-subtilis bioaerosols, J. Aerosol. Sci., 33, 1721-1723, 2002.

Lin, H., Lizarraga, L., Bottomley, L. A., and Carson Meredith, J.: Effect of water absorption on pollen adhesion, J. Colloid Interf. Sci., 442, 133-139, 2015.

Longest, P. W. and Holbrook, L. T.: In silico models of aerosol delivery to the respiratory tract - Development and applications, Adv. Drug Deliver. Rev., 64, 296-311, 2012.

Ma, Q. X., He, H., and Liu, Y. C.: In Situ DRIFTS Study of Hygroscopic Behavior of Mineral Aerosol, J. Environ. Sci., 22, 555560, 2010.

Melke, A.: The Physiology of Chilling Temperature Requirements for Dormancy Release and Bud-break in Temperate Fruit Trees Grown at Mild Winter Tropical Climate, Journal of Plant Studies, 4, 110-156, 2015

Möhler, O., DeMott, P. J., Vali, G., and Levin, Z.: Microbiology and atmospheric processes: the role of biological particles in cloud physics, Biogeosciences, 4, 1059-1071, https://doi.org/10.5194/bg-4-1059-2007, 2007.

Morris, C. E., Sands, D. C., Bardin, M., Jaenicke, R., Vogel, B., Leyronas, C., Ariya, P. A., and Psenner, R.: Microbiology and atmospheric processes: research challenges concerning the impact of airborne micro-organisms on the atmosphere and climate, Biogeosciences, 8, 17-25, https://doi.org/10.5194/bg-8-17-2011, 2011.

Morris, C. E., Conen, F., Alex Huffman, J., Phillips, V., Pöschl, U., and Sands, D. C.: Bioprecipitation: a feedback cycle linking Earth history, ecosystem dynamics and land use through biological ice nucleators in the atmosphere, Glob. Chang. Biol., 20, 341-351, 2014.

Murray, B. J., O’Sullivan, D., Atkinson, J. D., and Webb, M. E.: Ice nucleation by particles immersed in supercooled cloud droplets, Chem. Soc. Rev., 41, 6519-6554, 2012.

Najera, J. J., Percival, C. J., and Horn, A. B.: Infrared spectroscopic studies of the heterogeneous reaction of ozone with dry maleic and fumaric acid aerosol particles, Phys. Chem. Chem. Phys., 11, 9093-9103, 2009.

Noh, Y. M., Lee, H., Mueller, D., Lee, K., Shin, D., Shin, S., Choi, T. J., Choi, Y. J., and Kim, K. R.: Investigation of the diurnal pattern of the vertical distribution of pollen in the lower troposphere using LIDAR, Atmos. Chem. Phys., 13, 7619-7629, https://doi.org/10.5194/acp-13-7619-2013, 2013.

Pappas, C. S., Tarantilis, P. A., Harizanis, P. C., and Polissiou, M. G.: New method for pollen identification by FT-IR spectroscopy, Appl. Spectrosc., 57, 23-27, 2003.

Park, S. S. and Wexler, A. S.: Size-dependent deposition of particles in the human lung at steady-state breathing, J. Aerosol. Sci., 39, 266-276, 2008. 
Pasanen, A. L., Pasanen, P., Jantunen, M. J., and Kalliokoski, P.: Significance of air humidity and air velocity for fungal spore release into the air, Atmos. Environ., 25, 459-462, 1991.

Petters, M. D. and Kreidenweis, S. M.: A single parameter representation of hygroscopic growth and cloud condensation nucleus activity, Atmos. Chem. Phys., 7, 1961-1971, https://doi.org/10.5194/acp-7-1961-2007, 2007.

Pope, F. D.: Pollen grains are efficient cloud condensation nuclei, Environ. Res. Lett., 5, 044015, https://doi.org/10.1088/17489326/5/4/044015, 2010.

Pöschl, U., Martin, S. T., Sinha, B., Chen, Q., Gunthe, S. S., Huffman, J. A., Borrmann, S., Farmer, D. K., Garland, R. M., Helas, G., Jimenez, J. L., King, S. M., Manzi, A., Mikhailov, E., Pauliquevis, T., Petters, M. D., Prenni, A. J., Roldin, P., Rose, D., Schneider, J., Su, H., Zorn, S. R., Artaxo, P., and Andreae, M. O.: Rainforest Aerosols as Biogenic Nuclei of Clouds and Precipitation in the Amazon, Science, 329, 1513-1516, 2010.

Posselt, R. and Lohmann, U.: Influence of Giant CCN on warm rain processes in the ECHAM5 GCM, Atmos. Chem. Phys., 8, 37693788, https://doi.org/10.5194/acp-8-3769-2008, 2008.

Pratt, K. A., DeMott, P. J., French, J. R., Wang, Z., Westphal, D. L., Heymsfield, A. J., Twohy, C. H., Prenni, A. J., and Prather, K. A.: In situ detection of biological particles in cloud ice-crystals, Nat. Geosci., 2, 397-400, 2009.

Prenni, A. J., Petters, M. D., Kreidenweis, S. M., Heald, C. L., Martin, S. T., Artaxo, P., Garland, R. M., Wollny, A. G., and Pöschl, U.: Relative roles of biogenic emissions and Saharan dust as ice nuclei in the Amazon basin, Nat. Geosci., 2, 401-404, 2009.

Prisle, N. L., Lin, J. J., Purdue, S. K., Lin, H., Meredith, J. C., and Nenes, A.: CCN activity of six pollenkitts and the influence of their surface activity, Atmos. Chem. Phys. Discuss., https://doi.org/10.5194/acp-2018-394, in review, 2018.

Pummer, B. G., Bauer, H., Bernardi, J., Bleicher, S., and Grothe, H.: Suspendable macromolecules are responsible for ice nucleation activity of birch and conifer pollen, Atmos. Chem. Phys., 12, 2541-2550, https://doi.org/10.5194/acp-12-2541-2012, 2012.

Pummer, B. G., Bauer, H., Bernardi, J., Chazallon, B., Facq, S., Lendl, B., Whitmore, K., and Grothe, H.: Chemistry and morphology of dried-up pollen suspension residues, J. Raman Spectrosc., 44, 1654-1658, 2013.

Reinmuth-Selzle, K., Kampf, C. J., Lucas, K., Lang-Yona, N., Frohlich-Nowoisky, J., Shiraiwa, M., Lakey, P. S. J., Lai, S. C., Liu, F. B., Kunert, A. T., Ziegler, K., Shen, F. X., Sgarbanti, R., Weber, B., Bellinghausen, I., Saloga, J., Weller, M. G., Duschl, A., Schuppan, D., and Poschl, U.: Air Pollution and Climate Change Effects on Allergies in the Anthropocene: Abundance, Interaction, and Modification of Allergens and Adjuvants, Environ. Sci. Technol., 51, 4119-4141, 2017.

Reponen, T., Willeke, K., Ulevicius, V., Reponen, A., and Grinshpun, S. A.: Effect of relative humidity on the aerodynamic diameter and respiratory deposition of fungal spores, Atmos. Environ., 30, 3967-3974, 1996.

Schuttlefield, J. D., Al-Hosney, H., Zachariah, A., and Grassian, V. H.: Attenuated Total Reflection Fourier Transform Infrared Spectroscopy to Investigate Water Uptake and Phase Transitions in Atmospherically Relevant Particles, Appl. Spectrosc., 61, 283292, 2007a.

Schuttlefield, J. D., Cox, D., and Grassian, V. H.: An investigation of water uptake on clays minerals using ATR-
FTIR spectroscopy coupled with quartz crystal microbalance measurements, J. Geophys. Res.-Atmos., 112, D21303, https://doi.org/10.1029/2007JD008973, 2007b.

Shiraiwa, M., Ueda, K., Pozzer, A., Lammel, G., Kampf, C. J., Fushimi, A., Enami, S., Arangio, A. M., Frohlich-Nowoisky, J., Fujitani, Y., Furuyama, A., Lakey, P. S. J., Lelieveld, J., Lucas, K., Morino, Y., Poschl, U., Takaharna, S., Takami, A., Tong, H. J., Weber, B., Yoshino, A., and Sato, K.: Aerosol Health Effects from Molecular to Global Scales, Environ. Sci. Technol., 51, 13545-13567, 2017.

Skopp, J.: Derivation of the Freundlich Adsorption Isotherm from Kinetics, J. Chem. Educ., 86, 1341-1343, 2009.

Sofiev, M., Siljamo, P., Ranta, H., and Rantio-Lehtimäki, A.: Towards numerical forecasting of long-range air transport of birch pollen: theoretical considerations and a feasibility study, Int. J. Biometeorol., 50, 392-402, 2006.

Song, X. W. and Boily, J. F.: Water Vapor Adsorption on Goethite, Environ. Sci. Technol., 47, 7171-7177, 2013.

Steiner, A. L., Brooks, S. D., Deng, C. H., Thornton, D. C. O., Pendleton, M. W., and Bryant, V.: Pollen as atmospheric cloud condensation nuclei, Geophys. Res. Lett., 42, 3596-3602, 2015.

Stuart, B.: Infrared Spectroscopy: Fundamentals and Applications, John Wiley \& Sons, Ltd., New York, 2004.

Sun, J. M. and Ariya, P. A.: Atmospheric organic and bio-aerosols as cloud condensation nuclei $(\mathrm{CCN})$ : A review, Atmos. Environ., 40, 795-820, 2006.

Tang, M. J., Cziczo, D. J., and Grassian, V. H.: Interactions of Water with Mineral Dust Aerosol: Water Adsorption, Hygroscopicity, Cloud Condensation and Ice Nucleation, Chem. Rev., 116, 42054259, 2016.

Tang, M. J., Chen, J., and Wu, Z. J.: Ice nucleating particles in the troposphere: Progresses, challenges and opportunities, Atmos. Environ., 192, 206-208, 2018.

Taramarcaz, P., Lambelet, C., Clot, B., Keimer, C., and Hauser, C.: Ragweed (Ambrosia) progression and its health risks: will Switzerland resist this invasion?, Swiss Med. Wkly., 135, 538548, 2005.

Tong, H. J., Fitzgerald, C., Gallimore, P. J., Kalberer, M., Kuimova, M. K., Seville, P. C., Ward, A. D., and Pope, F. D.: Rapid interrogation of the physical and chemical characteristics of salbutamol sulphate aerosol from a pressurised metered-dose inhaler (pMDI), Chem. Commun., 50, 15499-15502, 2014.

Womack, A. M., Bohannan, B. J. M., and Green, J. L.: Biodiversity and biogeography of the atmosphere, Philos. T. R. Soc. B, 365, 3645-3653, 2010.

Yeh, H. C., Cuddihy, R. G., Phalen, R. F., and Chang, I. Y.: Comparisons of calculated respiratory tract deposition of particles based on the proposed NCRP model and the new ICRP66 model, Aerosol Sci. Tech., 25, 134-140, 1996.

Yeşilbaş, M. and Boily, J.-F.: Particle Size Controls on Water Adsorption and Condensation Regimes at Mineral Surfaces, Sci. Rep.-UK, 6, 32136, https://doi.org/10.1038/srep32136, 2016.

Yin, Y., Levin, Z., Reisin, T. G., and Tzivion, S.: The effects of giant cloud condensation nuclei on the development of precipitation in convective clouds - a numerical study, Atmos. Res., 53, 91-116, 2000 . 